\title{
ECONOMIC GROWTH EFFECTS OF PUBLIC AND PRIVATE INVESTMENT: EVIDENCE FROM DYNAMIC PANEL ESTIMATION FOR DEVELOPED AND DEVELOPING COUNTRIES*
}

\author{
Taner Turana iD, Halit Yanıkkayab iD, Hüseyin A. Özer ${ }^{b}$ iD
}

\begin{abstract}
We examine the growth effects of public and private investment by using data for a large sample of countries. For the full sample, our dynamic panel estimations indicate that both public and private investment have strong positive effects on growth. Our estimations for income levels also show that the impacts of both public and private investment are positive and statistically significant for developing countries. Interestingly, public and private investment promote growth in developing countries with effective and ineffective governments. It seems that countries can significantly benefit from investment regardless of their institutional quality levels. Furthermore, the effect of public investment generally appears to be larger than that of private investment. Given the robust relationship between investment and growth in both ineffective and effective developing countries, an important policy implication of our study is that both types of investment should be encouraged to foster economic growth.
\end{abstract}

Keywords: Growth, public and private investment, GMM, developing and developed countries, institutions

JEL Classification: C33, E22, O47

\section{Introduction}

With some notable exceptions, such as Khan and Reinhart (1990) and Barro (1990), the empirical literature on the growth effects of investment mostly ignores the difference between the public and private components. One may think that this might not be a significant concern when our focus is to examine the other key drivers of economic growth. However,

\footnotetext{
* The second author acknowledges support from the Turkish Academy of Sciences.

a Çukurova University, Department of Economics, Sarıcam/Adana, Turkey

b Gebze Technical University, Department of Economics, Gebze/Kocaeli, Turkey

Email: tturan@cu.edu.tr, halityanikkaya@gtu.edu.tr, aozer@gtu.edu.tr
} 
this does not rule out that this simplification matters and comes at a price. There is no doubt that the underlying dynamics and motivations of public and private investment decisions are not the same (see Milbourne et al., 2003, among others). For example, private investment mainly aims to capture the maximum profit based on net present value and cost-benefit analysis, while public investment should also consider some non-profit goals, externalities or spillover effects and adopt a longer time horizon and a broader perspective. Additionally, political economy considerations would matter for public investment decisions. Some early studies suggest that private investment has more growth-promoting effects than public investment (Khan and Reinhart, 1990; Serven and Solimano, 1992; Khan and Kumar, 1997). However, these predictions or estimations may change over time. In other words, on mere theoretical grounds there is no reason to expect or claim that private investment has necessarily a stronger effect on growth than public investment.

Could the effects of public and private investment on economic growth depend on income level? Since developed countries have a greater capital stock than developing countries, one would expect that marginal contribution of capital is more likely to be lower in developed countries compared to developing ones. Alternatively, it is possible to suggest that developed countries have required institutional capacity and economic means to direct investment projects to the most needed or productive areas. Furthermore, what is the role of institutional quality in explaining the growth effects of public and private investment? The importance of institutions for economic outcomes cannot be overemphasized (Acemoglu et al., 2001). One may argue that in countries with effective governments, investment decisions are more likely to be based on economic cost-andbenefit analysis, suggesting a higher probability of boosting the growth rate.

Motivated by aforementioned arguments, unlike many influential and pioneering studies such as Khan and Reinhart (1990), this study aims to shed light on the growth effects of public and private investment for a large sample of developing and developed countries by means of dynamic panel estimation methods. Our main contributions are three-fold. Firstly, we try to figure out the role of income level for the growth effects of public and private investment, suggested in the literature by Khan and Kumar (1997). Secondly, following Butkiewicz and Yanikkaya (2011), we test the importance of government effectiveness as a proxy for institutional quality for the effects of public and private investment. Although some studies, such as Keefer and Knack (2007) and Cavallo and Daude (2011), pay attention to the institutional quality in explaining the effects of public investment, there is no previous study focused particularly on government effectiveness in this context. Thirdly and importantly, we employ a dynamic panel estimation method for 125 countries over the period 1960-2014. In growth-related issues, it is a wellestablished fact that dynamic panel estimations are more suitable and reliable. 
Our results point out that a country's development level matters in explaining the growth effects of public and private investment. While neither public nor private investment seem to promote growth in developed countries, they raise growth substantially in developing countries. It is worth noting that this positive association holds for all developing countries regardless of their government effectiveness level. We should also note that the larger estimated coefficients for public investment than those for private investment clearly imply the significance of public investment for developing countries.

This paper is structured as follows. The next section reviews the literature about investment and growth. The third section presents data and methodological issues. The fourth section discusses the empirical results. Finally, the fifth section concludes the paper.

\section{Literature Review}

In the neoclassical Solow growth model, higher investment is not a source of sustained growth in the long run. During the transition period, higher investment is associated with higher growth rates, though (Solow, 1956). Moreover, endogenous growth models attribute an even more promising role to capital accumulation and related economic policies in explaining the economic growth. Since in these types of models the assumption of diminishing marginal returns may not be binding, changes in capital stock, namely investment, would be among the robust determinants of economic growth. In this context, some seminal studies, such as Levine and Renelt (1992) and Sala-i Martin (1997), empirically demonstrate the importance of investment for economic growth. On the other hand, it would be a grave mistake to assume that the growth effects of public and private investment are the same. Such an assumption is neither plausible nor realistic. It is clear that dynamics, determinants and outcomes of public and private investment would differ from each other (e.g., see Milbourne et al., 2003).

It is a well-known fact that public investment would have two opposing effects on growth (see Barro and Sala-i Martin, 1992). On the one hand, public investment would be effective and even deeply needed to remove bottlenecks in production processes, implying a direct positive effect. Without core or essential public investment, such as bridges, roads, railways, ports, etc., it is impossible to have any well-functioning economic activity and development. Therefore, some public investment spending is an obvious necessity for economic growth. Additionally, Agénor and Neanidis (2015) show that public investment has a positive influence on growth via human capital formation and innovation capacity. Not surprisingly, many studies report a positive relationship between public investment and economic growth. For example, Aschauer (1989) finds a significant positive relationship between public investment and economic growth 
for the USA. Easterly and Rebelo (1993) report that public investment in transportation and communication has a positive effect on growth. In a related study, Gwartney et al. (2006) demonstrate a significant positive effect of public investment on growth, but its magnitude is always smaller than that of private investment.

Moreover, public investment could potentially exert a positive indirect effect on growth through its impact on private investment (e.g., see Dreger and Reimers, 2016). Public investment would be complementary and boost both the level and productivity of private investment. Some studies, such as Erden and Holcombe (2005) for a panel of developing countries, Afonso and Aubyn (2019) for twelve OECD countries, and Şen and Kaya (2014) for Turkey, provide strong evidence for the positive impact of public investment on private investment.

On the other hand, there are also some obvious costs associated with public investment. The government budget constraint makes it clear that financing needs of an increase in public investment would distort the optimal allocation of scarce resources in an economy. All financing means, such as higher taxes, government debt or inflation, lead to fewer resources available for private use and hence more inefficiencies. Furthermore, if public investment is directed to produce goods competing with similar goods produced by the private sector, public and private investment will then be substitutes. Therefore, it is possible that under some conditions, public investment could crowd out private investment. For example, $\mathrm{Xu}$ and Yan (2014) for China, Bahal et al. (2018) for India, and Nguyen and Trinh (2018) for Vietnam find some empirical evidence for crowding-out effects. Additionally, at high levels of public capital stock, the marginal value of public investment will be low. Another argument, recently emphasized by Presbitero (2016), is related to absorptive capacity in the economy, including skills, institutions and management, implying that public investment cannot cause sustained output growth. As highlighted by Pritchett (1997), an increase in public investment may not lead to an equal or proportional rise in productive capital stock.

More importantly, public investment is heavily affected by political economy considerations and institutional quality, often ending up with "pork barrel projects", "white elephants" or "bridges to nowhere". Massive public investment projects might be a way of directing or transferring funds to powerful elite groups or supporters of incumbent governments (Robinson and Torvik, 2005; Maskin and Tirole, 2008). Consistent with this argument, Keefer and Knack (2007) document that public investment is higher in countries with weak institutions, indicating that growth maximization would not be the only aim of public investment spending.

Along these lines, some studies report a negative or insignificant effect of public investment on growth. In a seminal study, Barro (1990) argues that public investment has 
a positive but insignificant association with economic growth. Devarajan et al. (1996) indicate that the ratio of transportation and communication expenditure to total public investment have a negative association with growth for a sample of 43 less developed countries. For Tunisian data, Ghali (1998) reports a significant negative effect of public investment on economic growth. On the other hand, Milbourne et al. (2003) estimate two growth models to compare the effects of public investments on growth, namely the transition model and the steady-state model. Using the OLS method, in transition, there is a significant positive effect of public investment on growth but in steady state this association becomes insignificant. Moreover, Berg et al. (2019) show that increases in public investment in inefficient countries have a lower impact on growth than in efficient ones.

Some arguments utilized to assess the impact of public investment, such as diminishing marginal returns or the importance of institutions, could matter for private investment, too. In essence, decisions on private investment should also rely on economic costs and benefits, consistent with profit maximization motives. Therefore, private investment would potentially spur economic growth (e.g., see Khan and Reinhart, 1990; Bint-e-Ajaz and Ellahi, 2012). However, it is implausible to argue that all private investment decisions have a positive impact on economic activity. Put differently, it is misleading to consider that there exists an automatic or mechanical link between private investment and economic growth, implying that an increase in private investment will be necessarily associated with higher growth rates. Moreover, in the absence or lack of right incentives, motivations, prices, property rights, stability or predictability, private investment would concentrate on areas which are not the best or most needed for economic growth or social welfare in the long run (e.g., see, Dawson, 1998). This means that some private investment that would be profitable for entrepreneurs in the short term would not be growth-maximizing at the same time. Rather, inefficient private investment would result in retarding, not fostering, the growth rate (among others, see, Nazmi and Ramirez, 1997). Furthermore, it is also worth mentioning that private investment could affect growth processes by some channels such as inflation and terms of trade (Fischer, 1993), capital and labour growth (Lin, 1994), human capital and political instability (Barro, 1991; Romer, 1994).

\section{Model and Data}

Our paper employs the basic neoclassical growth model as follows:

$$
\begin{aligned}
& g_{i t}^{y}=\beta_{1} g_{i t-1}^{y}+\beta_{2} Y_{i t}+\sum_{j=1}^{m} \gamma_{j} X_{j i t}+\sum_{k=1}^{n} \delta_{k} Z_{k i t}+u_{i t} \\
& i=1, \ldots, N ; t=1, \ldots, T ; j=1, \ldots, m ; k=1, \ldots, n
\end{aligned}
$$


where $i$ denotes countries, $t$ refers to time, $j$ and $k$ are the indices for the number of control variables and different investment ratios, respectively. $g_{i t}^{y}$ is the real GDP per capita growth, $Y_{i t}$ is the $\log$ of initial GDP per capita for each 5-year periods, $X_{j i t}$ contains the control variables related to the growth determinants, $Z_{k i t}$ is the vector of different investment ratios and $u_{i t}$ is the error term. $X_{j i t}$ consists of government consumption, population growth, human capital index, trade openness, polity and inflation.

The series of real GDP per capita growth, population growth, basic trade shares (sum of exports and imports as percentage of GDP), general government final consumption expenditures (as a percentage of GDP) and inflation rate (annual averages) are taken from the World Bank's World Development Indicators. Initial GDP per capita and human capital index measures are from the Penn World Tables (see Feenstra et al., 2015). The human capital index ranges between 1 and 4, where larger scores mean higher levels of human capital. We employ the polity measure to control for the regime characteristics of countries. It is collected from the Polity IV Project, Political Regime Characteristics and Transitions database. The polity index ranges between -10 and 10 , where positive scores indicate democratic countries. We include total investment, general government (public) investment and private investment, all specified as percentages of GDP in our sample. All investment data are taken from Investment and Capital Stock Dataset of the International Monetary Fund. Lastly, to capture the long-run trends and purge the series of cyclical effects, we take the five-year non-overlapping averages of all samples beginning from the initial period 1960-1964 to 2010-2014. The mean values of the sample are presented in Table 1. A notable observation in Table 1 is that public investment ratios display similar patterns in both developed and developing countries. However, private investment ratios in both developed and effective developing countries are much higher. One can argue that better institutional quality and investment climate may explain the high levels of private investment in these countries.

Our dataset consists of 125 developed and developing countries. ${ }^{1}$ We also split our sample into two groups by using mean value of government effectiveness scores (see Kaufmann et al., 2011). Countries having effectiveness scores higher (lower) than the mean value are considered to be effective (ineffective) governments.

1 Income classification is based on the World Bank Country Classification. Based on the earliest fiscal year, 25 high-income countries are considered to be developed countries while the rest is identified as developing countries. At the end of 1987, countries with income of more than 6,000 GNI per capita in US\$ are classified as developed countries. https://databank.worldbank.org/data/ download/site-content/OGHIST.xls 
Table 1: Summary statistics

\begin{tabular}{|c|c|c|c|c|c|c|}
\hline Variable & $\begin{array}{l}\text { Observa- } \\
\text { tions }\end{array}$ & $\begin{array}{c}\text { All } \\
\text { Countries }\end{array}$ & $\begin{array}{l}\text { Developed } \\
\text { Countries }\end{array}$ & $\begin{array}{l}\text { Developing } \\
\text { Countries }\end{array}$ & $\begin{array}{c}\text { Effective } \\
\text { Governments }\end{array}$ & $\begin{array}{l}\text { Ineffective } \\
\text { Governments }\end{array}$ \\
\hline $\begin{array}{l}\text { GDP per capita } \\
\text { growth (\%) }\end{array}$ & 1,165 & 2.013 & 2.178 & 1.969 & 2.562 & 1.639 \\
\hline $\begin{array}{l}\text { Initial GDP per } \\
\text { capita (log) }\end{array}$ & 1,162 & 3.519 & 4.466 & 3.264 & 4.139 & 3.091 \\
\hline $\begin{array}{l}\text { Population } \\
\text { growth (\%) }\end{array}$ & 1,261 & 1.914 & 1.383 & 2.054 & 1.454 & 2.235 \\
\hline $\begin{array}{l}\text { Human capital } \\
\text { index }\end{array}$ & 1,239 & 2.058 & 2.837 & 1.849 & 2.588 & 1.685 \\
\hline $\begin{array}{l}\text { Trade openness } \\
\text { (\% of GDP) }\end{array}$ & 1,140 & 68.223 & 84.582 & 63.556 & 82.684 & 57.893 \\
\hline $\begin{array}{l}\text { Polity } \\
(-10 \text { to }+10)\end{array}$ & 1,250 & 1.515 & 7.052 & 0.032 & 5.292 & -1.166 \\
\hline $\begin{array}{l}\text { Government } \\
\text { consumption } \\
\text { (\% of GDP) }\end{array}$ & 1,132 & 14.975 & 18.505 & 13.933 & 17.248 & 13.283 \\
\hline Inflation (\%) & 1,298 & 35.197 & 5.643 & 42.600 & 32.223 & 51.700 \\
\hline $\begin{array}{l}\text { Total } \\
\text { investment } \\
\text { (\% of GDP) }\end{array}$ & 1,300 & 18.582 & 23.748 & 17.202 & 22.173 & 16.038 \\
\hline $\begin{array}{l}\text { Public } \\
\text { investment } \\
\text { (\% of GDP) }\end{array}$ & 1,300 & 5.321 & 4.788 & 5.463 & 5.044 & 5.517 \\
\hline $\begin{array}{l}\text { Private } \\
\text { investment } \\
(\% \text { of GDP) }\end{array}$ & 1,300 & 13.260 & 18.959 & 11.738 & 17.129 & 10.520 \\
\hline
\end{tabular}

Note: See the text for variable definitions and sources.

We choose to estimate our growth equations using the system generalized method of moments (GMM) method since the OLS and fixed-effects estimators have biased results when lagged dependent variables are considered as independent variables. Nickell (1981) argues that the pooled OLS (fixed-effects) estimators can generate upward (downward) biased estimations in the panel models. To solve the problem of inconsistency and panel bias in growth regressions, all empirical specifications are estimated using the system GMM. ${ }^{2}$ GMM estimators have been commonly utilized in empirical literature to compromise with many problems such as heteroscedasticity, overidentification, validity and, most importantly, endogeneity. In such cases, Baum et al. (2003) suggest that heteroscedasticity can be best avoided by the GMM estimators.

2 To do so, we utilize the "xtabond2" command from Roodman (2009), with a two-step robust estimator. 
Baum et al. (2007) show that the Hansen test is applied to overidentification restrictions for considering the validity of the instrument set. Therefore, the number of instruments should be lower than or equal to the number of cross-sectional units, and we test the instrument appropriateness using the Hansen test. The higher $p$-values in all the estimation tables indicate that our instrument set is exogenous and valid. Moreover, to test for autocorrelation, $\mathrm{AR}(1)$ and $\mathrm{AR}(2)$ tests are applied in our estimations. We observe that $\mathrm{AR}(1)$ tests are significant (not reported) while $\operatorname{AR}(2)$ tests are insignificant. This means that autocorrelation is present in the AR(1) level, though we indicate that there is no autocorrelation in the AR(2) level.

Additionally, Bazzi and Clemens (2013) state that in growth regressions, researchers should use GMM estimators to gauge instrument efficiency. Further, dynamic panel estimations could produce too many instruments. Therefore, the weak instrumentation problem may emerge in panel regressions (see Roodman, 2009). To deal with the weak instrumentation problem, a general rule of thumb emphasizes that the number of instruments should be near to the number of cross-sectional units. In our panel, we have over 100 cross-sectional units and we use the "collapse" option in all our specifications to refrain from using too many instruments.

\section{Empirical Results and Discussion}

Our system GMM regression results are reported in Table $2 .{ }^{3}$ The statistically significant and positive coefficients of the lagged growth rates imply that growth is persistent over time. Negative coefficients of initial GDP lend substantial evidence for the convergence hypothesis across the sample of countries. As expected, the human capital index has a significantly positive impact on growth. While government consumption has an insignificantly negative effect, inflation significantly reduces growth.

In the Column 1 of Table 2, we first employ the total investment variable without differentiating between its public and private components. The estimation result shows that total investment has a significantly positive relationship with growth, confirming the well-known role of investment. As our focus in this paper is to pay particular attention to possible differences between the growth effects of public and private investment, we then focus on the results in Columns 2, 3 and 4. It seems that both public and private investment promote growth when separately or jointly included in the estimations. These results make it clear that public investment has a positive impact on growth even when we control

3 We also checked the sensitivity of our estimates by excluding lagged growth rates in the main specification and obtain qualitatively similar results for different samples. These estimations are not reported, but available upon request. 
for private investment, implying that public investment directly affects growth. Note that the magnitudes of the estimated coefficients of public investment are substantially greater than those of private investment.

Table 2: Investment and growth: full sample

\begin{tabular}{|c|c|c|c|c|}
\hline & (1) & (2) & (3) & (4) \\
\hline Lagged growth rates & $\begin{array}{c}0.111^{* *} \\
(2.288)\end{array}$ & $\begin{array}{l}0.154^{* * *} \\
(3.201)\end{array}$ & $\begin{array}{l}0.138^{* * *} \\
(2.721)\end{array}$ & $\begin{array}{l}0.113^{* *} \\
(2.289)\end{array}$ \\
\hline Initial GDP (log) & $\begin{array}{l}-5.515^{* * *} \\
(-4.571)\end{array}$ & $\begin{array}{l}-2.620^{* *} \\
(-2.444)\end{array}$ & $\begin{array}{l}-5.480^{* * *} \\
(-4.539)\end{array}$ & $\begin{array}{l}-4.425^{* * *} \\
(-3.733)\end{array}$ \\
\hline Government consumption & $\begin{array}{l}-0.0477 \\
(-0.566)\end{array}$ & $\begin{array}{l}-0.104 \\
(-1.357)\end{array}$ & $\begin{array}{l}-0.0250 \\
(-0.345)\end{array}$ & $\begin{array}{l}-0.0684 \\
(-0.780)\end{array}$ \\
\hline Population growth & $\begin{array}{l}-0.437 \\
(-1.122)\end{array}$ & $\begin{array}{l}-0.541 \\
(-1.331)\end{array}$ & $\begin{array}{c}-0.543 \\
(-1.403)\end{array}$ & $\begin{array}{l}-0.441 \\
(-1.192)\end{array}$ \\
\hline Human capital index & $\begin{array}{l}4.870^{* * *} \\
(3.478)\end{array}$ & $\begin{array}{l}3.438^{* *} \\
(2.546)\end{array}$ & $\begin{array}{l}4.689^{* * *} \\
(3.465)\end{array}$ & $\begin{array}{l}4.119^{* * *} \\
(3.024)\end{array}$ \\
\hline Trade openness & $\begin{array}{c}-0.00136 \\
(-0.144)\end{array}$ & $\begin{array}{c}0.00879 \\
(1.036)\end{array}$ & $\begin{array}{c}0.00379 \\
(0.388)\end{array}$ & $\begin{array}{l}4.87 e-05 \\
(0.00568)\end{array}$ \\
\hline Polity & $\begin{array}{l}-0.0157 \\
(-0.260)\end{array}$ & $\begin{array}{l}0.0561 \\
(0.860)\end{array}$ & $\begin{array}{l}0.0186 \\
(0.283)\end{array}$ & $\begin{array}{c}-0.000938 \\
(-0.0157)\end{array}$ \\
\hline Inflation & $\begin{array}{l}-0.00182^{* * *} \\
(-6.134)\end{array}$ & $\begin{array}{c}-0.00131^{* * *} \\
(-3.757)\end{array}$ & $\begin{array}{c}-0.00164^{* * *} \\
(-3.574)\end{array}$ & $\begin{array}{c}-0.00160^{* * *} \\
(-4.573)\end{array}$ \\
\hline Total investment & $\begin{array}{l}0.236^{* * *} \\
(5.718)\end{array}$ & - & - & - \\
\hline Public investment & - & $\begin{array}{l}0.462^{* * *} \\
(4.657)\end{array}$ & - & $\begin{array}{l}0.397^{* * *} \\
(4.141)\end{array}$ \\
\hline Private investment & - & - & $\begin{array}{l}0.228^{* * *} \\
(3.301)\end{array}$ & $\begin{array}{l}0.177^{* * *} \\
(3.504)\end{array}$ \\
\hline Number of observations & 881 & 881 & 881 & 881 \\
\hline Number of countries & 125 & 125 & 125 & 125 \\
\hline Number of IVs & 108 & 108 & 108 & 119 \\
\hline AR (2) & 0.653 & 0.802 & 0.447 & 0.798 \\
\hline Hansen test & 0.207 & 0.079 & 0.211 & 0.251 \\
\hline
\end{tabular}

Notes: t-statistics are in parentheses. ${ }^{* * *},{ }^{* *}$ and ${ }^{*}$ denote the $1 \%, 5 \%$ and $10 \%$ significance level, respectively. Time dummies are employed (but not reported) in all specifications. The standard errors are computed in accordance with Windmeijer's (2005) finite sample correction. AR(2) test reports the $p$-value of second order autocorrelation. Hansen J-test reports the $p$-values for the null hypothesis of instrument validity.

Source: Authors' calculations 
Table 3: Investment and growth: by income level

\begin{tabular}{|c|c|c|c|c|c|c|c|c|}
\hline & \multicolumn{4}{|c|}{ Developed } & \multicolumn{4}{|c|}{ Developing } \\
\hline & (1) & (2) & (3) & (4) & (5) & (6) & (7) & (8) \\
\hline $\begin{array}{l}\text { Lagged } \\
\text { growth rates }\end{array}$ & $\begin{array}{l}0.0966 \\
(0.724)\end{array}$ & $\begin{array}{c}0.196^{* *} \\
(2.672)\end{array}$ & $\begin{array}{c}0.188 \\
(1.550)\end{array}$ & $\begin{array}{l}0.0825 \\
(0.492)\end{array}$ & $\begin{array}{c}0.118^{* *} \\
(2.331)\end{array}$ & $\begin{array}{l}0.157^{* * *} \\
(2.991)\end{array}$ & $\begin{array}{c}0.160^{* * * *} \\
(3.010)\end{array}$ & $\begin{array}{l}0.105^{* *} \\
(2.127)\end{array}$ \\
\hline $\begin{array}{l}\text { Initial GDP } \\
\text { (log) }\end{array}$ & $\begin{array}{c}1.826 \\
(0.192)\end{array}$ & $\begin{array}{l}-7.816^{*} \\
(-1.825)\end{array}$ & $\begin{array}{l}-4.002 \\
(-1.344)\end{array}$ & $\begin{array}{c}-1.993 \\
(-0.284)\end{array}$ & $\begin{array}{c}-6.330^{* * *} \\
(-2.998)\end{array}$ & $\begin{array}{l}-2.506 \\
(-1.613)\end{array}$ & $\begin{array}{l}-5.520^{* * *} \\
(-3.164)\end{array}$ & $\begin{array}{l}-5.265^{* * *} \\
(-3.391)\end{array}$ \\
\hline $\begin{array}{l}\text { Government } \\
\text { consumption }\end{array}$ & $\begin{array}{l}0.0300 \\
(0.305)\end{array}$ & $\begin{array}{l}-0.0720 \\
(-1.570)\end{array}$ & $\begin{array}{l}-0.0281 \\
(-0.720)\end{array}$ & $\begin{array}{l}-0.0318 \\
(-0.536)\end{array}$ & $\begin{array}{l}-0.0187 \\
(-0.208)\end{array}$ & $\begin{array}{l}-0.0829 \\
(-0.822)\end{array}$ & $\begin{array}{l}-0.0149 \\
(-0.201)\end{array}$ & $\begin{array}{l}-0.0469 \\
(-0.438)\end{array}$ \\
\hline $\begin{array}{l}\text { Population } \\
\text { growth }\end{array}$ & $\begin{array}{c}-0.442 \\
(-1.237)\end{array}$ & $\begin{array}{c}-0.102 \\
(-0.281)\end{array}$ & $\begin{array}{l}-0.200 \\
(-0.571)\end{array}$ & $\begin{array}{c}-0.232 \\
(-0.879)\end{array}$ & $\begin{array}{c}-0.467 \\
(-0.842)\end{array}$ & $\begin{array}{l}-0.578 \\
(-1.002)\end{array}$ & $\begin{array}{l}-0.681 \\
(-1.072)\end{array}$ & $\begin{array}{l}-0.429 \\
(-0.743)\end{array}$ \\
\hline $\begin{array}{l}\text { Human } \\
\text { capital index }\end{array}$ & $\begin{array}{c}1.531 \\
(1.388)\end{array}$ & $\begin{array}{l}1.355^{* * *} \\
(2.848)\end{array}$ & $\begin{array}{c}1.479^{*} \\
(1.837)\end{array}$ & $\begin{array}{c}1.061 \\
(0.986)\end{array}$ & $\begin{array}{c}4.982^{* * *} \\
(2.297)\end{array}$ & $\begin{array}{c}2.986^{* *} \\
(2.110)\end{array}$ & $\begin{array}{l}4.128^{* *} \\
(2.112)\end{array}$ & $\begin{array}{l}4.269^{* *} \\
(2.582)\end{array}$ \\
\hline $\begin{array}{l}\text { Trade } \\
\text { openness }\end{array}$ & $\begin{array}{c}-0.00686 \\
(-0.834)\end{array}$ & $\begin{array}{l}0.0105 \\
(1.247)\end{array}$ & $\begin{array}{c}0.00263 \\
(0.513)\end{array}$ & $\begin{array}{c}0.00100 \\
(0.159)\end{array}$ & $\begin{array}{c}0.000817 \\
(0.0641)\end{array}$ & $\begin{array}{c}0.00963 \\
(0.818)\end{array}$ & $\begin{array}{c}0.00841 \\
(0.628)\end{array}$ & $\begin{array}{c}0.00255 \\
(0.212)\end{array}$ \\
\hline Polity & $\begin{array}{l}-0.231 \\
(-1.251)\end{array}$ & $\begin{array}{l}0.0651 \\
(0.609)\end{array}$ & $\begin{array}{l}-0.0941 \\
(-0.808)\end{array}$ & $\begin{array}{l}-0.0985 \\
(-0.650)\end{array}$ & $\begin{array}{c}0.00888 \\
(0.162)\end{array}$ & $\begin{array}{l}0.0370 \\
(0.546)\end{array}$ & $\begin{array}{l}0.0140 \\
(0.267)\end{array}$ & $\begin{array}{l}0.0139 \\
(0.228)\end{array}$ \\
\hline Inflation & $\begin{array}{c}-0.00292 \\
(-0.321)\end{array}$ & $\begin{array}{c}0.00612 \\
(1.249)\end{array}$ & $\begin{array}{c}-0.00109 \\
(-0.112)\end{array}$ & $\begin{array}{c}0.00122 \\
(0.173)\end{array}$ & $\begin{array}{c}-0.0017^{* * *} \\
(-3.908)\end{array}$ & $\begin{array}{c}-0.0014^{* * * *} \\
(-3.764)\end{array}$ & $\begin{array}{c}-0.0019^{* * *} \\
(-4.492)\end{array}$ & $\begin{array}{c}-0.0016^{* * *} \\
(-4.091)\end{array}$ \\
\hline $\begin{array}{l}\text { Total } \\
\text { investment }\end{array}$ & $\begin{array}{c}0.261^{* *} \\
(2.103)\end{array}$ & $\begin{array}{l}- \\
-\end{array}$ & $\begin{array}{l}- \\
-\end{array}$ & - & $\begin{array}{l}0.268^{* * * *} \\
(5.216)\end{array}$ & $\begin{array}{l}- \\
-\end{array}$ & $\begin{array}{l}- \\
-\end{array}$ & $\begin{array}{l}- \\
-\end{array}$ \\
\hline $\begin{array}{l}\text { Public } \\
\text { investment }\end{array}$ & - & $\begin{array}{l}0.0578 \\
(0.176)\end{array}$ & - & $\begin{array}{c}0.173 \\
(0.974)\end{array}$ & - & $\begin{array}{l}0.460^{* * *} \\
(4.758)\end{array}$ & - & $\begin{array}{l}0.431^{* * * *} \\
(4.309)\end{array}$ \\
\hline $\begin{array}{l}\text { Private } \\
\text { investment }\end{array}$ & - & - & $\begin{array}{c}0.136 \\
(1.111)\end{array}$ & $\begin{array}{l}0.0811 \\
(0.665)\end{array}$ & - & - & $\begin{array}{l}0.256^{* * *} \\
(3.366)\end{array}$ & $\begin{array}{l}0.217^{* * * *} \\
(3.594)\end{array}$ \\
\hline $\begin{array}{l}\text { Number } \\
\text { of observa- } \\
\text { tions }\end{array}$ & 215 & 215 & 215 & 215 & 666 & 666 & 666 & 666 \\
\hline $\begin{array}{l}\text { Number } \\
\text { of countries }\end{array}$ & 25 & 25 & 25 & 25 & 100 & 100 & 100 & 100 \\
\hline $\begin{array}{l}\text { Number } \\
\text { of IVs }\end{array}$ & 24 & 24 & 24 & 26 & 91 & 91 & 91 & 100 \\
\hline AR (2) & 0.573 & 0.886 & 0.816 & 0.743 & 0.395 & 0.557 & 0.256 & 0.551 \\
\hline Hansen test & 0.330 & 0.188 & 0.0329 & 0.241 & 0.242 & 0.172 & 0.332 & 0.320 \\
\hline
\end{tabular}

Notes: t-statistics are in parentheses. ${ }^{* * *},{ }^{* *}$ and ${ }^{*}$ denote the $1 \%, 5 \%$ and $10 \%$ significance level, respectively. Time dummies are employed (but not reported) in all specifications. The standard errors are computed in accordance with Windmeijer's (2005) finite sample correction. AR(2) test reports the $p$-value of second order autocorrelation. Hansen J-test reports the $p$-values for the null hypothesis of instrument validity.

Source: Authors' calculations 
To obtain additional insights, we then divide our sample into two groups, namely developing and developed countries, and report the results in Table 3. As for the growth controls, the initial GDP per capita has a significantly negative effect on growth only in developing countries, indicating income convergence among them. Inflation has a significantly negative impact on growth only in developing countries in line with Barro (1996). Lastly, the human capital index seems to raise growth in developing countries as in Teixeira and Quieros (2016).

We find that total investment has a significantly positive effect on growth in developed countries. However, estimates in Columns 2, 3 and 4 reveal that public and private investment do not significantly and individually contribute to growth in developed countries. Our results do not lend evidence for the argument that the level of capital stock is already adequate or high in developed countries and thus the contribution of an increase in capital stock will be less or even be negative in some cases.

As for developing countries, we find that total investment significantly promotes growth (see Column 5 of Table 3). Moreover, our results suggest that both public and private investment have positive impacts on growth (see, Columns 6, 7 and 8). In other words, unlike in developed countries, increases in public or private investment lead to higher growth in developing countries. Importantly, as measured with the size of the coefficients, the impact of public investment is stronger than that of private investment. Our findings are particularly important given that developing countries have inadequate levels of investment or capital stock. When there is less capital available, then its marginal contribution is expected to be high. This argument can be expanded more by noting that the lower the overall capital stock, the higher the probability that public and private investment are complementary rather than substitutes. In a broader sense, our results suggest that developing countries need more physical investment. However, a caveat is in order. Our empirical results should not be interpreted in a way that even some "pork barrel" or "white elephant" investment projects will necessarily boost growth. Such interpretation is obviously not consistent with basic economic reasoning. We think that it is critical to establish an institutional structure or mechanism to ensure the efficient allocation of public funds among alternative means and encourage private investment towards welldefined and most needed areas. Of course, this is easier said than done. On the other hand, this is an important step to maintaining the positive link between investment and growth.

Note that our results differ from those of some studies in the literature such as Khan and Reinhart (1989) and Khan and Kumar (1997) for developing countries, since we fail to find any evidence for the argument that private investment has a more growth-promoting effect than public investment. However, our results are in line with many studies, such as Easterly and Rebelo (1993), reporting a positive impact of public investment on growth. 
Table 4: Investment and growth: by government effectiveness level

\begin{tabular}{|c|c|c|c|c|c|c|c|c|}
\hline & \multicolumn{4}{|c|}{ Effective } & \multicolumn{4}{|c|}{ Ineffective } \\
\hline & (1) & (2) & (3) & (4) & (5) & (6) & (7) & (8) \\
\hline $\begin{array}{l}\text { Lagged growth } \\
\text { rates }\end{array}$ & $\begin{array}{l}0.0916 \\
(1.513)\end{array}$ & $\begin{array}{c}0.131 \\
(1.399)\end{array}$ & $\begin{array}{c}0.135^{*} \\
(1.734)\end{array}$ & $\begin{array}{l}0.0895 \\
(1.042)\end{array}$ & $\begin{array}{l}0.0681 \\
(0.901)\end{array}$ & $\begin{array}{l}0.137^{* *} \\
(2.021)\end{array}$ & $\begin{array}{l}0.0846 \\
(1.154)\end{array}$ & $\begin{array}{l}0.0884 \\
(1.178)\end{array}$ \\
\hline Initial GDP (log) & $\begin{array}{l}-4.571^{* *} \\
(-2.500)\end{array}$ & $\begin{array}{l}-2.460 \\
(-1.640)\end{array}$ & $\begin{array}{l}-3.856^{*} \\
(-1.855)\end{array}$ & $\begin{array}{l}-4.047^{*} \\
(-2.013)\end{array}$ & $\begin{array}{l}-4.470^{*} \\
(-1.992)\end{array}$ & $\begin{array}{c}1.245 \\
(0.305)\end{array}$ & $\begin{array}{l}-3.357^{* *} \\
(-2.146)\end{array}$ & $\begin{array}{l}-3.053^{* *} \\
(-2.079)\end{array}$ \\
\hline $\begin{array}{l}\text { Government } \\
\text { consumption }\end{array}$ & $\begin{array}{l}-0.179 \\
(-1.622)\end{array}$ & $\begin{array}{l}-0.203^{*} \\
(-1.782)\end{array}$ & $\begin{array}{c}-0.162 \\
(-1.359)\end{array}$ & $\begin{array}{l}-0.164 \\
(-1.330)\end{array}$ & $\begin{array}{l}-0.207 \\
(-1.349)\end{array}$ & $\begin{array}{l}-0.243 \\
(-1.287)\end{array}$ & $\begin{array}{c}-0.115 \\
(-0.800)\end{array}$ & $\begin{array}{c}-0.151 \\
(-0.802)\end{array}$ \\
\hline $\begin{array}{l}\text { Population } \\
\text { growth }\end{array}$ & $\begin{array}{l}-1.277^{* * *} \\
(-3.440)\end{array}$ & $\begin{array}{l}-1.305^{\text {*** }} \\
(-4.845)\end{array}$ & $\begin{array}{l}-1.395^{* * *} \\
(-3.597)\end{array}$ & $\begin{array}{l}-1.281^{* * *} \\
(-4.423)\end{array}$ & $\begin{array}{l}1.096^{* *} \\
(2.162)\end{array}$ & $\begin{array}{l}1.321^{*} \\
(1.970)\end{array}$ & $\begin{array}{l}1.205^{* *} \\
(2.378)\end{array}$ & $\begin{array}{l}1.228^{* *} \\
(2.491)\end{array}$ \\
\hline $\begin{array}{l}\text { Human capital } \\
\text { index }\end{array}$ & $\begin{array}{c}0.487 \\
(0.350)\end{array}$ & $\begin{array}{c}1.789 \\
(1.412)\end{array}$ & $\begin{array}{c}0.359 \\
(0.277)\end{array}$ & $\begin{array}{c}1.173 \\
(0.529)\end{array}$ & $\begin{array}{l}4.895^{* *} \\
(2.521)\end{array}$ & $\begin{array}{c}0.621 \\
(0.214)\end{array}$ & $\begin{array}{l}4.044^{* *} \\
(2.647)\end{array}$ & $\begin{array}{l}4.261^{* *} \\
(2.461)\end{array}$ \\
\hline $\begin{array}{l}\text { Trade } \\
\text { openness }\end{array}$ & $\begin{array}{c}0.00904 \\
(0.577)\end{array}$ & $\begin{array}{c}-0.00257 \\
(-0.168)\end{array}$ & $\begin{array}{c}0.00572 \\
(0.378)\end{array}$ & $\begin{array}{l}-0.00238 \\
(-0.0832)\end{array}$ & $\begin{array}{l}0.0152 \\
(0.914)\end{array}$ & $\begin{array}{l}0.0671^{* * *} \\
(3.126)\end{array}$ & $\begin{array}{l}0.0286^{*} \\
(1.908)\end{array}$ & $\begin{array}{l}0.0156 \\
(1.028)\end{array}$ \\
\hline Inflation & $\begin{array}{c}-0.00251^{*} \\
(-1.981)\end{array}$ & $\begin{array}{c}-0.00175^{* *} \\
(-2.199)\end{array}$ & $\begin{array}{c}-0.00226^{*} \\
(-1.901)\end{array}$ & $\begin{array}{c}-0.00210 \\
(-1.169)\end{array}$ & $\begin{array}{c}-0.00170^{* * * *} \\
(-4.655)\end{array}$ & $\begin{array}{c}-0.00153^{* * *} \\
(-3.980)\end{array}$ & $\begin{array}{c}-0.00209^{* * *} \\
(-5.216)\end{array}$ & $\begin{array}{l}-0.00145^{\text {*** }} \\
(-4.460)\end{array}$ \\
\hline $\begin{array}{l}\text { Total } \\
\text { investment }\end{array}$ & $\begin{array}{l}0.183^{* * *} \\
(2.731)\end{array}$ & - & - & - & $\begin{array}{l}0.321^{* * *} \\
(4.133)\end{array}$ & - & - & - \\
\hline $\begin{array}{l}\text { Public } \\
\text { investment }\end{array}$ & $\begin{array}{l}- \\
-\end{array}$ & $\begin{array}{l}0.332^{* *} \\
(2.317)\end{array}$ & $\begin{array}{l}- \\
-\end{array}$ & $\begin{array}{l}0.346^{* *} \\
(2.253)\end{array}$ & - & $\begin{array}{l}0.409^{* *} \\
(2.248)\end{array}$ & - & $\begin{array}{l}0.362^{* * *} \\
(2.838)\end{array}$ \\
\hline $\begin{array}{l}\text { Private } \\
\text { investment }\end{array}$ & - & $\begin{array}{l}- \\
-\end{array}$ & $\begin{array}{l}0.169^{* *} \\
(2.439)\end{array}$ & $\begin{array}{l}0.150^{* *} \\
(2.127)\end{array}$ & - & - & $\begin{array}{l}0.332^{* * *} \\
(3.575)\end{array}$ & $\begin{array}{l}0.251^{* *} \\
(2.198)\end{array}$ \\
\hline $\begin{array}{l}\text { Number } \\
\text { of observations }\end{array}$ & 290 & 290 & 290 & 290 & 380 & 380 & 380 & 380 \\
\hline $\begin{array}{l}\text { Number } \\
\text { of countries }\end{array}$ & 42 & 42 & 42 & 42 & 58 & 58 & 58 & 58 \\
\hline Number of IVs & 50 & 50 & 50 & 55 & 58 & 58 & 58 & 64 \\
\hline $\operatorname{AR}(2)$ & 0.540 & 0.392 & 0.688 & 0.471 & 0.391 & 0.268 & 0.386 & 0.324 \\
\hline Hansen test & 0.532 & 0.707 & 0.487 & 0.755 & 0.422 & 0.123 & 0.382 & 0.532 \\
\hline
\end{tabular}

Notes: t-statistics are in parentheses. ${ }^{* * *},{ }^{* *}$ and ${ }^{*}$ denote the $1 \%, 5 \%$ and $10 \%$ significance level, respectively. Time dummies are employed (but not reported) in all specifications. The standard errors are computed in accordance with Windmeijer's (2005) finite sample correction. AR(2) test reports the $p$-value of second order autocorrelation. Hansen J-test reports the $p$-values for the null hypothesis of instrument validity.

Source: Authors' calculations

Based on the literature reviewed above (Keefer and Knack, 2007; Pritchett, 1997; Robinson and Torvik, 2005; Maskin and Tirole, 2008), it is imperative to investigate whether the growth effects of total, public and private investment depend on the government effectiveness level of developing countries. Note that we choose not to include developed countries with much higher government effectiveness scores since our estimates would be 
biased towards effective governments. ${ }^{4}$ Our aim is to figure out whether institutions matter for the growth effects of investment. In this context, we use the mean values of government effectiveness in our sample to classify the countries. If a developing country's effectiveness score is larger than the sample mean, this developing country is described as having an effective government. Similarly, developing countries with lower scores than the sample mean are considered as having ineffective governments. In essence, developing countries with effective (ineffective) governments have strong (weak) institutions.

Table 4 presents the system GMM estimation results for effective and ineffective governments. Regarding the control variables, we should point out to the existence of sharp differences between the effects of population growth and the human capital index for effective and ineffective governments. There is a significant negative (positive) relationship between population growth and income growth in effective (ineffective) governments. The human capital index also has a significant (insignificant) positive impact on growth in countries with ineffective (effective) governments as in Turan and Yanikkaya (2020).

Our estimations show that total investment has a significantly positive impact for both effective and ineffective governments. Note that the estimated coefficient of total investment is much higher for ineffective governments than that for effective governments. One possible explanation for this result is that since capital formation is relatively lower in ineffective governments, the growth impact of additional investment could be much higher (see Butkiewicz and Yanikkaya, 2011). More importantly, the growth effects of both public and private investment are significantly positive for both groups of developing countries. Note that when we include both public and private investment in the same specification, we also obtain significantly positive estimates. Public investment has a favourable effect on growth even when we control for private investment, clearly implying that the role of public investment for growth is not limited only to encouraging private investment. These significant results imply that public or private investment affects growth independently. Therefore, despite some anectodal evidence for problems about public investment decisions and implementations in countries with ineffective governments, the difference between effective and ineffective governments does not seem to be solid.

\section{Conclusion}

Our paper examines the growth effects of both public and private investment by using panel data for a large sample of countries. For the full sample, our GMM results indicate that total investment raises growth. Our results also show that both public and private investment have a robust positive effect on growth. We then divide our sample based on income levels.

4 Table in the Appendix section lists all the countries and also indicates developing countries with effective or ineffective governments. 
While total investment has a significantly positive impact on growth in developed countries, both public and private investment promote growth in developing countries.

Using a government effectiveness measure as a proxy for institutional quality, we then investigate whether institutional quality matters in explaining the growth effects of public and private investment in developing countries. Our findings indicate that both public and private investment improve growth in developing countries regardless of their government effectiveness levels. Note that these significant coefficients continue to survive even when we include public and private investment jointly in the same specification. This implies that government effectiveness does not play a decisive role in this context. In other words, it is not required to have an effective government to benefit from investment, which suggests a strong return to investment and also highlights the importance of investment in the development process.

We would like to note and highlight some important points based on our empirical findings. Firstly, since to evaluate the argument whether public and private investment have separate impacts or to gauge whether public or private investment has a larger direct effect, it is important to differentiate between public and private investment when examining the growth effects of investment measures. Secondly, the growth effects of public and private investment depend on income levels. As for developing countries, since both public and private investment play a positive role in growth, more investment should be encouraged, which is the most important policy implication derived from this study. Creating a stable and predictable investor-friendly environment would be helpful to support private investment. Additionally, establishing an efficient and transparent system or procedure to evaluate the possible impacts or returns of different public investment projects would be very helpful. Such a system could also help to avoid the possible negative influence of political economy considerations. Thirdly, although both public and private investment have a positive impact on growth in some specifications, the coefficient of public investment is consistently greater than that of private investment. This clearly indicates the importance of public investment for developing countries. Fourthly, public or private investment raises growth regardless of the level of institutional quality, i.e., government effectiveness, which does not lend any significant evidence for the argument that developing countries are in need of a certain level of development to benefit from public or private investment. We think that this particular result has important policy implications. Since it is relatively more challenging to improve the government effectiveness level in the short term compared to increasing investment, our results are more encouraging. Despite presenting strong evidence for the direct growth effects of public and private investment in developing countries, our results do not evaluate through which channels public and private investment would affect the growth rate. We think that it would be fruitful for future studies to focus on pinning down these channels empirically. 


\section{Appendix}

\section{List of countries}

\begin{tabular}{|c|c|c|c|}
\hline Albaniab $^{b}$ & Germany* & New Zealand* & Uruguay $^{\mathrm{a}}$ \\
\hline Algeriab $^{b}$ & Ghana $^{a}$ & Nicaraguab & Venezuelab $^{b}$ \\
\hline Angolab $^{b}$ & Greece $^{a}$ & Niger $^{\mathrm{b}}$ & Vietnam $^{b}$ \\
\hline Armenia $^{a}$ & Guatemalab $^{\mathrm{b}}$ & Nigeriab $^{b}$ & Zambiab $^{b}$ \\
\hline Australia* & Honduras $^{\mathrm{b}}$ & Norway* & Zimbabwe $^{b}$ \\
\hline Austria* & Hungary $^{a}$ & Pakistan $^{\text {b }}$ & \\
\hline Bahrain* & India ${ }^{a}$ & Panama $^{a}$ & \\
\hline Bangladesh $^{\mathrm{b}}$ & Indonesiab $^{\mathrm{b}}$ & Paraguay $^{\mathrm{b}}$ & \\
\hline Belgium* & $\operatorname{Iran}^{b}$ & Perua & \\
\hline Benin $^{b}$ & Iraq $^{b}$ & Philippines $^{\mathrm{a}}$ & \\
\hline Boliviab $^{\mathrm{b}}$ & Ireland* & Poland ${ }^{a}$ & \\
\hline Botswana $^{a}$ & Israel* & Portugala & \\
\hline Brazil $^{\text {a }}$ & Italy* & Qatar* & \\
\hline Bulgaria $^{a}$ & Japan* & Romania $^{a}$ & \\
\hline Burkina Faso ${ }^{b}$ & Jordan $^{\mathrm{a}}$ & Russiab $^{b}$ & \\
\hline Burundi ${ }^{b}$ & Kazakhstan $^{\mathrm{b}}$ & Rwanda $^{b}$ & \\
\hline Cambodiab $^{b}$ & Kenya $^{\mathrm{b}}$ & Saudi Arabiaa & \\
\hline Cameroon $^{b}$ & Korea, South ${ }^{a}$ & Senegal ${ }^{\mathrm{a}}$ & \\
\hline Canada* & Kuwait* & Serbia $^{a}$ & \\
\hline Central African Republic ${ }^{b}$ & Kyrgyzstan ${ }^{b}$ & Sierra Leone ${ }^{\mathrm{b}}$ & \\
\hline Chile $^{\mathrm{a}}$ & Laos $^{b}$ & Singapore* & \\
\hline China $^{\mathrm{a}}$ & Latvia $^{a}$ & Slovakia $^{a}$ & \\
\hline Colombia $^{b}$ & Lesotho $^{\mathrm{a}}$ & Slovenia ${ }^{a}$ & \\
\hline Congo Democratic Republic ${ }^{b}$ & Liberia $^{b}$ & South Africa ${ }^{\mathrm{a}}$ & \\
\hline Costa Rica $^{a}$ & Lithuania $^{a}$ & Spain* & \\
\hline Cote $d^{\prime}$ Ivoire ${ }^{b}$ & Luxembourg* & Sri Lankab & \\
\hline Croatia $^{a}$ & Madagascarb & Sudan ${ }^{b}$ & \\
\hline Czech Republic $^{\mathrm{a}}$ & Malawi ${ }^{b}$ & Sweden* & \\
\hline Denmark* & Malaysia $^{a}$ & Switzerland* & \\
\hline Dominican Republic $^{b}$ & Malib $^{b}$ & Tajikistan $^{\mathrm{b}}$ & \\
\hline Ecuadorb $^{\mathrm{b}}$ & Mauritania $^{a}$ & Tanzania $^{b}$ & \\
\hline Egypt $^{b}$ & Mauritius $^{\mathrm{a}}$ & Thailand $^{a}$ & \\
\hline El Salvador ${ }^{b}$ & Mexico $^{a}$ & Togo $^{b}$ & \\
\hline Estonia $^{\mathrm{a}}$ & Moldova $^{\mathrm{b}}$ & Tunisia $^{a}$ & \\
\hline Ethiopiab $^{b}$ & Mongoliab $^{b}$ & Turkey $^{\mathrm{a}}$ & \\
\hline $\mathrm{Fiji}^{\mathrm{b}}$ & Morocco $^{a}$ & Uganda $^{b}$ & \\
\hline Finland* & Myanmar ${ }^{\mathrm{b}}$ & Ukraine $^{\mathrm{b}}$ & \\
\hline France* $^{*}$ & Namibia $^{a}$ & United Arab Emirates ${ }^{a}$ & \\
\hline Gabon $^{b}$ & $\mathrm{Nepal}^{\mathrm{b}}$ & United Kingdom* & \\
\hline Gambiab $^{b}$ & Netherlands* & United States* & \\
\hline
\end{tabular}

Note: ${ }^{*}$ denotes developed countries. ${ }^{\mathrm{a}}$ and ${ }^{\mathrm{b}}$ represent developing countries with effective and ineffective governments, respectively.

Source: Based on World Bank Country Classification and Kaufmann et al. 2011. 


\section{References}

Acemoglu, D., Johnson, S., Robinson, J. A. (2001). The Colonial Origins of Comparative Development: An Empirical Investigation. American Economic Review, 91(5), 1369-1401, https://doi.org/10.3386/w7771

Afonso, A., Aubyn, M. S. (2019). Economic Growth, Public, and Private Investment Returns in 17 OECD Economies. Portuguese Economic Journal, 18(1), 47-65, https://doi.org/10.1007/s10258-018-0143-7

Agénor, P. R., Neanidis, K. C. (2015). Innovation, Public Capital, and Growth. Journal of Macroeconomics, 44, 252-275, https://doi.org/10.1016/j.jmacro.2015.03.003

Aschauer, D. A. (1989). Is Public Expenditure Productive? Journal of Monetary Economics, 23(2), 177-200, https://doi.org/10.1016/0304-3932(89)90047-0

Bahal, G., Raissi, M., Tulin, V. (2018). Crowding-out or Crowding-in? Public and Private Investment in India. World Development, 109, 323-333, https://doi.org/10.1016/j. worlddev.2018.05.004

Barro, R. J. (1990). Government Spending in a Simple Model of Endogeneous Growth. Journal of Political Economy, 98(5, Part 2), 103-125, https://doi.org/10.1086/261726

Barro, R. J. (1991). Economic Growth in a Cross Section of Countries. The Quarterly Journal of Economics, 106(2), 407-443, https://doi.org/10.2307/2937943

Barro, R. J. (1996). Inflation and Growth. Review-Federal Reserve Bank of Saint Louis, 78(3), 153-169, https://doi.org/10.20955/r.78.153-169

Barro, R. J., Sala-i-Martin, X. (1992). Convergence. Journal of Political Economy, 100(2), 223-251, https://doi.org/10.1086/261816

Baum, C. F., Schaffer, M. E., Stillman, S. (2003). Instrumental Variables and GMM: Estimation and Testing. The Stata Journal, 3(1), 1-31, https://doi.org/10.1177/1536867X0300300101

Baum, C. F., Schaffer, M. E., Stillman, S. (2007). Enhanced Routines for Instrumental Variables/ Generalized Method of Moments Estimation and Testing. The Stata Journal, 7(4), 465-506, https://doi.org/10.1177/1536867X0800700402

Bazzi, S., Clemens, M. A. (2013). Blunt Instruments: Avoiding Common Pitfalls in Identifying the Causes of Economic Growth. American Economic Journal: Macroeconomics, 5(2), 152-186, https://doi.org/10.1257/mac.5.2.152

Berg, A., Buffie, E. F., Pattillo, C., et al. (2019). Some Misconceptions about Public Investment Efficiency and Growth. Economica, 86(342), 409-430, https://doi.org/10.1111/ecca.12275

Bint-e-Ajaz, M., Ellahi, N. (2012). Public-private Investment and Economic Growth in Pakistan: An Empirical Analysis. The Pakistan Development Review, 51(4), 61-77.

Butkiewicz, J. L., Yanikkaya, H. (2011). Institutions and the Impact of Government Spending on Growth. Journal of Applied Economics, 14(2), 319-341, https://doi.org/10.1016/ s1514-0326(11)60017-2 
Cavallo, E., Daude, C. (2011). Public Investment in Developing Countries: A Blessing or a Curse? Journal of Comparative Economics, 39(1), 65-81, https://doi.org/10.1016/j. jce.2010.10.001

Dawson, J. W. (1998). Institutions, Investment, and Growth: New Cross-country and Panel Data Evidence. Economic Inquiry, 36(4), 603-619, https://doi.org/10.1111/j.1465-7295.1998. tb01739.x

Devarajan, S., Swaroop, V., Zou, H. F. (1996). The Composition of Public Expenditure and Economic Growth. Journal of Monetary Economics, 37(2), 313-344, https://doi.org/10.1016/s0304-3932(96)90039-2

Dreger, C., Reimers, H. E. (2016). Does Public Investment Stimulate Private Investment? Evidence for the Euro Area. Economic Modelling, 58, 154-158, https://doi.org/10.1016/j. econmod.2016.05.028

Easterly, W., Rebelo, S. (1993). Fiscal Policy and Economic Growth. Journal of Monetary Economics, 32(3), 417-458, https://doi.org/10.1016/0304-3932(93)90025-b

Erden, L., Holcombe, R. G. (2005). The Effects of Public Investment on Private Investment in Developing Economies. Public Finance Review, 33(5), 575-602, https://doi.org/10.1177/1091142105277627

Feenstra, R. C., Inklaar, R., Timmer, M. P. (2015). The Next Generation of the Penn World Table. American Economic Review, 105(10), 3150-3182, https://doi.org/10.1257/aer.20130954

Fischer, S. (1993). The Role of Macroeconomic Factors in Growth. Journal of Monetary Economics, 32(3), 485-512, https://doi.org/10.1016/0304-3932(93)90027-d

Ghali, K. H. (1998). Public Investment and Private Capital Formation in a Vector Errorcorrection Model of Growth. Applied Economics, 30(6), 837-844, https://doi. org/10.1080/000368498325543

Gwartney, J. D., Holcombe, R. G., Lawson, R. A. (2006). Institutions and the Impact of Investment on Growth. Kyklos, 59(2), 255-273, https://doi.org/10.1111/j.1467-6435.2006.00327.x

Kaufmann, D., Kraay, A., Mastruzzi, M. (2011). The Worldwide Governance Indicators: Methodology and Analytical Issues. Hague Journal on the Rule of Law, 3(2), 220-246, https://doi.org/10.1017/s1876404511200046

Keefer, P., Knack, S. (2007). Boondoggles, Rent-seeking, and Political Checks and Balances: Public Investment Under Unaccountable Governments. The Review of Economics and Statistics, 89(3), 566-572, https://doi.org/10.1162/rest.89.3.566

Khan, M. S., Kumar, M. S. (1997). Public and Private Investment and the Growth Process in Developing Countries. Oxford Bulletin of Economics and Statistics, 59(1), 69-88, https://doi.org/10.1111/1468-0084.00050

Khan, M. S., Reinhart, C. M. (1990). Private Investment and Economic Growth in Developing Countries. World Development, 18(1), 19-27, https://doi.org/10.1016/0305-750x(90)90100-c

Levine, R., Renelt, D. (1992). A Sensitivity Analysis of Cross-country Growth Regressions. The American Economic Review, 82(4), 942-963. 
Lin, S. A. (1994). Government Spending and Economic Growth. Applied Economics, 26(1), 83-94, https://doi.org/10.1080/00036849400000064

Maskin, E., Tirole, J. (2008). Public-private Partnerships and Government Spending Limits. International Journal of Industrial Organization, 26(2), 412-420, https://doi.org/10.1016/j.ijindorg.2007.05.004

Milbourne, R., Otto, G., Voss, G. (2003). Public Investment and Economic Growth. Applied Economics, 35(5), 527-540, https://doi.org/10.1080/0003684022000015883

Nazmi, N., Ramirez, M. D. (1997). Public and Private Investment and Economic Growth in Mexico. Contemporary Economic Policy, 15(1), 65-75, https://doi.org/10.1111/j.1465-7287.1997.tb00455.x

Nguyen, C. T., Trinh, L. T. (2018). The Impacts of Public Investment on Private Investment and Economic Growth: Evidence from Vietnam. Journal of Asian Business and Economic Studies, 25(1), 15-32, https://doi.org/10.1108/jabes-04-2018-0003

Nickell, S. (1981). Biases in Dynamic Models with Fixed Effects. Econometrica, 49(6), 1417-1426, https://doi.org/10.2307/1911408

Presbitero, A. F. (2016). Too Much and Too Fast? Public Investment Scaling-up and Absorptive Capacity. Journal of Development Economics, 120, 17-31, https://doi.org/10.1016/j. jdeveco.2015.12.005

Pritchett, L. (1997). Divergence, Big Time. Journal of Economic Perspectives, 11(3), 3-17, https://doi.org/10.1257/jep.11.3.3

Robinson, J. A., Torvik, R. (2005). White Elephants. Journal of Public Economics, 89(2-3), 197-210, https://doi.org/10.1016/j.jpubeco.2004.05.004

Romer, P. M. (1994). The Origins of Endogenous Growth. Journal of Economic Perspectives, 8(1), 3-22, https://doi.org/10.1257/jep.8.1.3

Roodman, D. (2009). How to Do Xtabond2: An Introduction to Difference and System GMM in Stata. The Stata Journal, 9(1), 86-136, https://doi.org/10.1177/1536867x0900900106

Sala-i-Martin, X. X. (1997). I Just Ran Four Million Regressions. National Bureau of Economic Research. Cambridge, MA Working Paper No. 6252, https://doi.org/10.3386/w6252

Şen, H., Kaya, A. (2014). Crowding-out or Crowding-in? Analyzing the Effects of Government Spending on Private Investment in Turkey. Panoeconomicus, 61 (6), 631-651, https://doi.org/10.2298/pan1406631s

Serven, L., Solimano, A. (1992). Private Investment and Macroeconomic Adjustment: A Survey. The World Bank Research Observer, 7(1), 95-114, https://doi.org/10.1093/wbro/7.1.95

Solow, R. M. (1956). A Contribution to the Theory of Economic Growth. The Quarterly Journal of Economics, 70(1), 65-94, https://doi.org/10.2307/1884513

Teixeira, A. A., Queirós, A. S. (2016). Economic Growth, Human Capital and Structural Change: A Dynamic Panel Data Analysis. Research Policy, 45(8), 1636-1648, https://doi.org/10.1016/j.respol.2016.04.006 
Turan, T., Yanıkkaya, H. (2020). External Debt, Growth and Investment for Developing Countries: Some Evidence for the Debt Overhang Hypothesis. Portuguese Economic Journal, 1-23, https://doi.org/10.1007/s10258-020-00183-3

Windmeijer, F. (2005). A Finite Sample Correction for the Variance of Linear Efficient Two-step GMM Estimators. Journal of Econometrics, 126(1), 25-51, https://doi.org/10.1016/j. jeconom.2004.02.005

Xu, X., Yan, Y. (2014). Does Government Investment Crowd Out Private Investment in China? Journal of Economic Policy Reform, 17(1), 1-12, https://doi.org/10.1080/17487870.2013.8 66897 